\title{
A Comparative Analysis of the U.S. Mainstream Press and Black Press Coverage of Jean-Bertrand Aristide from 1991-2011
}

Amar N. Spencer*

Media Production, California, USA

\begin{abstract}
This study examined how the U.S. mainstream press and the Black Press portrayed former Haitian President Jean-Bertrand Aristide from 1991-2011. Using narrative analysis, this study found that the mainstream press primarily depicted him as a savior of poor Haitians, and as a corrupt politician. The Black Press portrayed him in the same manner, but also depicted him as a victim of U.S. foreign policy. The findings led to the conclusion that the coverage by the Black Press is often similar to that of the mainstream. However, the Black Press is, at times, more inclined than the mainstream to challenge the U.S. status quo.
\end{abstract}

Keywords: Black Press; U.S. Media; Haiti; Press; Civilize

\section{Introduction}

A country in the Caribbean plagued by abject poverty and governed by corrupt leaders; this is often the U.S. media's depiction of Haiti. Seemingly, Haiti has been a focal point for U.S. journalists during times of natural disasters and political disquiet. As Gans [1] posits, the U.S. media has the tendency to cover foreign countries mostly during times of natural disasters and political unrest. Instances in which the U.S. media paid considerable attention to Haiti include: the mega earthquake in Haiti in 2010, the cholera outbreak later that year, and the 2011 return of two of the island's most well-known and ousted politicians-Jean-Claude "Baby Doc" Duvalier and JeanBertrand Aristide.

Honing in on reports of Aristide, the twice-deposed Haitian president has been given relatively extensive coverage since his rise to presidency in 1991. Aristide is Haiti's first-democratically elected president who was ousted after a coup in 1991; re-instated by the U.S. in 1994; and ousted again in 2004 [2]. He made numerous U.S. headlines over the years. By 2011, the former Catholic priest-who by then had been living in exile in South Africa after being ousted for the second time in 2004-was once again the subject of many media reports. The surge in reports came after he announced that he planned to end his exile by returning to Haiti.

\section{Research questions}

Against that backdrop, this thesis focused on the portrayal of Aristide from 1991-2011.My research questions were:

a) What were the main narratives about Aristide in the Black Press and the mainstream press in the U.S. from 1991-2011?

b) What were the similarities and differences between the coverage by both types of newspapers?

\section{Significance of this study}

Given the longstanding history between the U.S. and Haiti, an analysis of U.S news coverage of one of Haiti's former leaders is important to consider. Also, with Haiti being a stone's throw from the southern border of the U.S., obvious implications exist for Americans when major developments occur there, as Fauriol [3] points out. This, too, establishes the importance of Haiti developments being reported by the U.S. news media and the significance of studying coverage of the happenings.
Research on the Black Press coverage is necessary so that a comparison/contrast can be drawn between the two types of media. As Deuze argues, ethnic media embrace "dialogical discourse" as opposed to the "monological" practices of the mainstream media [4]. Such a comparison is needed to help to build on existing research of ethnic/ Black Press' coverage of minority events in the Third World. It is only through a comparative study that differences/similarities between the Black press and the mainstream can be observed. Additionally, given the exponential growth rate of ethnic/minority media in the U.S. over the years Deuze [4] research on ethnic media coverage becomes even more important.

Summary of Chapters to Come: Chapter two explores Haiti's history and studies on media coverage of the country, as well as outlines applicable theories. Chapter 3 focuses on the methodology of the study; in Chapter 4, iReport, analyze, and assess the findings of the research. Conclusions are drawn in the final section, Chapter 5.

\section{Literature Review}

As previously mentioned, Haiti's history is a key element in understanding the island's current condition and the U.S.' position towards Aristide. Hence, this literature review will first outline the island's history with the U.S; then examine previous studies on the U.S. media's coverage of the republic; and lastly explore applicable theoretical frameworks that relate to the U.S.' coverage of Haiti.

\section{Haiti's history}

My aim here is to show the present-day plight of the people within the context of the state's history, since history paves the way for today's conditions. Chomsky et al. [5] note that "a quick review of Haiti's history is indispensible to understanding the current muddle" [5]. Also, Ulysse underscores: "Haiti's history would become its only

${ }^{*}$ Corresponding author: Amar N. Spencer, Media Production, California, E-mail: amar_spencer@hotmail.com

Received June 04, 2012; Accepted November 27, 2012; Published December 05, 2012

Citation: Spencer AN (2012) A Comparative Analysis of the U.S. Mainstream Press and Black Press Coverage of Jean-Bertrand Aristide from 1991-2011. J Mass Commun Journalism 2:136. doi:10.4172/2165-7912.1000136

Copyright: (c) 2012 Spencer AN. This is an open-access article distributed under the terms of the Creative Commons Attribution License, which permits unrestricted use, distribution, and reproduction in any medium, provided the original author and source are credited. 
defense against these portrayals, although in the mainstream media that same history would be used against the republic by historical revisionists" [6]

\section{Early history}

A mere 15 years after the U.S. declared its independence from Great Britain, "its colonial regime came under threat in August 1791, when the enslaved majority (in Haiti) rebelled; inaugurating what would become the Haitian Revolution" [5]. Haitians' ideology was based on the notion that "all men, regardless of race, are free, equal, and entitled to the rights of citizens" [5]. According to White, the 13 years that ensued were fraught with violence as the slaves fought for their freedom and the U.S. had no choice but to pay attention to the revolution as it unfolded.

These revolts in Haiti gave birth to "the largest slave uprising in history" in 1804, which ultimately resulted in the island's independence from France that year [7]. Haitians' feat of becoming the first black republic in the Western Hemisphere left the U.S. with no choice but to "ponder the implications of the Haitian Revolution for the viability of their nation" [7]. Chomsky argues that the U.S. tried its utmost to "strangle" Haiti, including backing France in its mandate that Haiti pay reparations.

In its reaction to Haiti's independence, the U.S., as an emerging world power, projected its "insecurities" onto Haiti [8]. One key channel through which these insecurities were relayed was through literature, such as poetry and news articles. As Dash points out, the U.S. often classified the island as other, in its nineteenth-century writings.

These negative and peripheral depictions of the island were linked to the fact that Haiti was the first black Republic, which "challenged the whole system of slavery and notions of black inferiority" [8]. What continued to grow throughout that entire period of the nineteenth century was the U.S. representation of blacks as cooks, gardeners, maids, and so forth?

By 1889 , the U.S. attempted to acquire the Haitian town, Mole St. Nicholas, as a naval station, arousing Haitians' suspicion and distrust of the American government [8]. As a result of this uneasy feeling that Haitians felt towards Americans, the U.S' plans were foiled. This was because the idea of having "white foreigners on Haitian soil" did not rest well on the minds of Haitians [8]. As Haitians' fears of returning to slavery mounted, Haitian commentators voiced their disquiet. Their fear was that they would now become enslaved by "American masters" and Haitian media personalities focused their commentary on "how degraded and unprotesting the American black had become to prove to their fellow islanders that Haiti could not return to enslavement [8].

By the beginning of the twentieth century, Haiti would face yet another challenge in its already-strained relationship with the U.S. According to Schmidt, America was emerging as the dominant power in the Caribbean, following the withdrawal of large units of British West Indian troops in 1905. The Americans feared that the Germanswho had greater naval capabilities than the U.S, would pose a challenge to American power. Consequently, America occupied the Caribbean republic from 1915 to 1934 in what historians see as a step to maintain American hegemony in the Caribbean at the time.

The U.S.' rationale for occupying Haiti was that the islanders were too inferior to control their own state of affairs and the Americans were needed to "civilize" the "backward" islanders [9]. The HaitianAmerican Treaty of 1915-which Schmidt describes as a "unilateral document executed by the State Department"-was often used by the U.S. to justify its presence in Haiti, when, in fact, the treaty could have been repealed at any time [9].

The economic policy adopted by the U.S. was centered around American economic expansion into the island, with an emphasis being placed on agriculture and "manual-technical" education for Haitians [9].Notably, literacy among Haitians and education on democracy were kept off the U.S.' agenda. The Americans created roads, hospitals and other public infrastructure with the hope that Haiti, "despite the alleged inferiority of Haitians, would be developed into a prosperous country with the help of American leadership and technological genius" [9].

Moreover, Americans were inculcated with bigotry [9]. The writer notes that concurrent with the American Occupation of Haiti were the savage treatments of Indians in the U.S., the lynching of immigrants, Ku Klux Klan prejudice, "oriental exclusion" and the "systematic suppression of blacks" [9]. Thus, the Americans who went to Haiti carried with them the notions that blacks were "gooks" and "niggers" and that they were "genetically and culturally inferior" [9] Even President Hoover's decision to send educated black Americans to Haiti "to investigate Haitian education" proved futile [9].According to Schmidt, the U.S. Navy refused to transport the educated blacks when they arrived on the island.

Conversely, Schmidt adds, there was dissenting opinion within the U.S. about the Occupation. Anti-imperialists "charged that the Marines invaded Haiti as bill collectors for the National City Bank of New York" [9] and added that the invasion was in contravention with the "American doctrines of democracy and individual liberty" [9].Schmidt encapsulates the dissidents' proclamations, stating: "The absolutely authoritarian character of the Occupation, the unchallenged military dictation, suppression of local democratic institutions, and jailing of Haitian newspaper editors prompted vigorous denunciations from American idealists who saw in the occupation a dangerous breach in American political morality" [9].

In 1922, Haitian lawyer and former foreign minister Louis Borno was chosen by the Council of State as president of the republic and he ruled with an iron fist [10]. Lawmaking decisions, Millspaugh notes, were based on advice and consent from the American High Commissioner Col. John H. Russell, who was appointed by U.S. President Warren Harding earlier that year as "ambassador extraordinary" between the U.S. and Haiti.

Meantime, Renda [11] notes the numerous challenges to the Occupation from the period of 1918 to early 1922. The Cacos-the name given to Haitian rebels-had an ongoing war against the forced labor and expropriation of Haiti's land that came along with the Occupation. Moreover, Renda [11] adds that African American associates in the National Association for the Advancement of Colored People (NAACP) also had their own anti-occupation movement. When these African Americans returned to the U.S, they spread the anti-occupation sentiments by telling stories about the grim realities of the invasion.

Renda [11] also mentions the rise in prostitution during the U.S' presence on the island. As she explains, prostitution became more lucrative in the short run than the furthering of agricultural and manufacturing units on the island. "Although it is unlikely that prostitution was unknown to Port-au-Prince before the U.S occupation, as one Haitian critic claimed, still the sex industry grew with the extraordinary infusion of American money and men into the 
capital city" [11]. Soon syphilis and other STDs spiked and so, too, did "illegitimate children."

By the fall of 1929, tax increases and changes to the scholarship policy for students who attended the agriculture college run by the U.S. Marines revived the anti-Occupation stance [11]. As a result, thousands of students took to the streets in protest against the Occupation and its Borno dictatorship. The downfall of the Marines' occupation would occur on December 6, 1929, when the U.S. soldiers opened fire on the protestors in Aux Cayes in southern Haiti, killing 12 people and injuring 23. "The Cayesmassacre led to international condemnation of the occupation, thus forcing the U.S. president to act" [11].

President Hoover then chose a commission to investigate the Haiti situation and the commission members noted the general antioccupation feeling throughout the world [11]. Shortly after, Stenio Vincent was legislatively elected president in November 1930, and the commission recommended the exit of the U.S. Marines. "Four years later, on August 15, 1934, the long-awaited desoccupation came to pass, as the last U.S. Marines departed" [11].

Despite the U.S.' pullout from Haiti, a relationship remained between the two states. According to Smith, during the year of the pullout, trade between the two states peaked. The U.S. granted a 25year contract to the Standard Fruit and Steamship Company to develop the island's banana industry. There was also a rubber-cultivation agreement, with one of Haiti's hopes being that it would help to boost the country's economy. A grant of $\$ 5$ million was given by the ExportImport Bank in Washington in 1941 to aid in the development of the rubber plants. Two years later, more than 47,000 acres of land were cleared to accommodate rubber cultivation. However, the project was not without problems. Many peasant families were forced out of their homes to facilitate the cultivation. Money invested to get rubber from the hevea trees went to waste, for the most part, when the trees did not yield as much rubber as originally projected. By May 1944, the project was deemed a failure.

The rubber experiment left the government "bankrupt and ravaged by disappointment," and at the same time, the banana industry collapsed, and coffee exports decreased [12]. Furthermore, the State Department's demands for payment on an outstanding $\$ 700,000$ loan from 1922 put the country into a deeper financial slump. Commenting on the post-occupation relations between the U.S. and Haiti, Smith (2009) states: "Instead of improving the local economy, these new relations contributed to the harsh conditions faced by the peasantry and the urban workers" [12].

In 1947, a team of Haitians travelled to Washington to negotiate for a moratorium on Haiti's loans, including loan forgiveness on a 1938 arrangement, and a new $\$ 20$ million loan to repay debts incurred during the Occupation and the development of the agricultural businesses [12]. However, the Haitian delegation was turned down on the vague grounds that the proposal contained a "lack of detailed information on individual projects that the loan was intended to service" [12]. This rejection forced the delegation to conclude that the U.S. "preferred to support rebuilding efforts in war-ravaged Europe and leave Haiti in turmoil and confusion" [12].

\section{The Duvalier's Reign}

Haiti experienced its longest dictatorship under the leadership of Francois 'Papa Doc' Duvalier and Jean-Claude 'Baby Doc' Duvalier from 1957-1986 [13]. Shortly after Francois' entry into office on September 22, 1957, he closed, undermined or made ineffective, civilian institutions such as schools, universities, professional associations, and churches. He also closed the few remaining independent news outlets on the island and journalists were either imprisoned or tortured. As for Haiti's relationship with the U.S. at the time, tension was present between Francois and President Kennedy, but the relationship would soon change with Kennedy's death and, later, the election of Richard Nixon.

Appealing to the U.S.' strong anti-communism ideology, Francois successfully persuaded the world power to fund construction of the Francois Duvalier International Airport in exchange for Haiti's vote for the ousting of Cuba from the Organization of American States (OAS). To fulfill his end of the bargain, the Haitian president instituted the "Anti-Communist Law of April 1969" [14].

Upon Francois' death in early 1971, Washington endorsed his 19-year-old son Jean-Claude Duvalier's "access to presidency" [13]. By the mid-1980s, Haiti's inordinate debt, its failed trading agreements with the U.S, and Jean-Claude's corruption placed the country into a deeper slump. Aid monies from the U.S. were deposited into the dictator's bank accounts and the country's previous economic conditions had led to the quadrupling of the deficit between 1975 and 1981. Jean-Claude was accused of stealing $\$ 500$ million from Haiti, not including the large sums he personally spent. Consequently, by the mid-1980s, the cost of food and housing skyrocketed. Haitians reached their boiling point and took to the streets. On February 7, 1986, JeanClaude, his wife, and some followers left the island in a plane allegedly sanctioned by the "highest levels of the U.S. Executive" [13].

Duvalier was replaced by a National Council of Government (CNG), which the U.S. pronounced would help to make Haiti a democracy [13]. But, "by the end of its first year in office the CNG, generously helped by U.S. tax payers' money, had openly gunned down more civilians than Jean-Claude Duvalier's government had done in fifteen years" [13].

\section{Aristide's Reign}

Aristide, a former priest, was elected president in February 1991, with some of his priorities being to provide health services, curb corruption, address the high cost of living, and so forth [2]. His election "appalled" the U.S. government because of the former priest's proletariat supporters [14]. Shortly after Aristide took office, Haiti experienced a US $\$ 127$ million reduction in its public debt. However, seven months later he was overthrown by the Haitian military, which Aristide believed came about as a result of his threat to the armed forces power [2]

Wucker notes that Aristide was not able to allay the elites' fears that his poor supporters would turn against them. Another factor that led to his government's demise in 1991 was his critique of the then President of the Dominican Republic Joaquin Balaguer. In response, Balaguer banished thousands of Haitians who were living in the Dominican Republic at the time.

The U.S. publicly supported Aristide but privately undermined him [2]. In 1994, President Clinton deployed U.S. troops to Haiti to remove the military from power and re-instate Aristide. As Dupuy [2] notes, this move by the U.S. was in spite of its "dislike" for Aristide. Given the U.S.' "post-Cold War neoliberal agenda,"-in which U.S. hegemony is maintained-Dupuy [2] asserts that the U.S. had no choice but to publicly oppose the coup d'état. Problems in the Third World would translate to "difficulties for the United States in its efforts to create a new and more stable world order" [2]. Fauriol [3] points out that the 
U.S. reinstalled the former Haitian president so that democracy can be restored, but the principal goal was for political order to be returned.

Furthermore, in 1991, the Organization of American States (OAS) vowed to "suspend the membership of any state whose democratically elected government was overthrown by a coup" [2]. Thus, a coup in Haiti would have signaled an imminent suspension of Haiti from the OAS, and would have weakened the U.S.' case that Cuba was the only non-democratic government in the Western Hemisphere.

However, to avoid cutting its longstanding ties with the Haitian military and elites, the U.S. forced Aristide to compromise with the Haitian military and the affluent middle class. Clinton also reinstalled the former priest because the political upheaval surrounding Aristide's ouster caused hundreds of Haitians to seek refuge in the U.S. Clinton was fearful that mass migration of Haitians would translate to a "domestic political crisis" in the U.S. [15]. Doyle suggests that the U.S.' policy on Haiti from then on should have been clear-cut rather than ambiguous [16]. Reading adds that the U.S.' policy on Haiti, after the Cold War, should have been one focused on fostering democracy as opposed to developing the island's military [17].

Shortly after Aristide's re-instatement into office in 1994, a Human Rights Watch Report noted that human rights abuse cases in Haiti had improved "significantly" (Human Rights Watch, 1995, p. 1). Conceding that some crimes were still committed after Aristide's return to presidency, the report stated that roughly 20 Haitians were killed from January to October of 1995 but "the Aristide government has not been linked credibly to any of these cases" [18].

Republicans soon controlled the U.S. Congress and "worked to block or burden with conditions aid to the impoverished, strife-torn Haiti" [5]. Morley and McGillion [19] note that at times of political changes in Latin America the U.S.' objective is to maintain its "continuity". U.S. aid to Haiti went to the opposition, and in 2000, the U.S. attempted to "freeze international aid as well" [5]. Aristide was pressured by international leaders to adhere to the economic reform plans such as those laid out by the International Monetary Fund (IMF) [20]. Increasing tax collection, cutting fuel subsidies, laying off government workers are among the measures stipulated by the IMF and proved to be "politically disabling" for Aristide [18]. Soon, Haiti became impossible to govern because of the mass poverty and violence that erupted as a result of the international sanctions on the island [15].

By 2004, on February 28, Aristide was ousted by an armed rebellion of former members of the Haitian military that was disbanded in 1995 [14]. Alleged human rights abuses by the police; the end of talks between the government and opposition; and crimes committed by "pro-Aristide gangs" are among the reasons for the 2004 rebellion [21]. The leader had also "alienated" Haitians who once supported him [20].

Reeves counters rhetorically questioning whether any leader could rule under the circumstances that Aristide faced. Pressure from the U.S. and international lending institutions, the dissenting Haitian elite, and the growing demands of the Haitian people are among the challenges Aristide encountered during his second term in office [22]. Ballve [15] add that the ouster of the former priest falls in line with the U.S.'practice of overthrowing leaders in Latin America who do not conform to its ideology.

Aristide claimed he was kidnapped and taken to a French military base in Central African Republic (CAR) [5]. The former Haitian president has gone on the record stating the U.S.' involvement in his ouster [5].Aristide is reported to have said: "I didn't leave Haiti because I wanted to leave Haiti. They forced me to leave Haiti. It was a kidnapping, which they call coup d'état. It wasn't a resignation" [5].

Wucker argues that the U.S.' focus on Aristide's personality as opposed to the country's need for institutional advancement played a great role in undoing Haiti's vulnerable democracy. This posed "major obstacles" for the island's future advancement and resulted in Haiti becoming a "dangerously polarized nation" [20]. Chomsky suggests that the U.S. and France should have aided Haiti to come out of its slump by paying the Caribbean country "enormous reparations" [14].

Thus, to sum up the reasons behind the U.S.' obsession with Haiti, Preeg [23] notes that while the U.S. does not have any major commercial interests in Haiti, the country's demographic and development factors, as well as its geographic proximity to the U.S. make it of interest. Events in foreign countries interest the U.S. media when the happenings have an effect on "Americans or American interests" $[1,23]$ underscores that Haiti falls under the category of poor countries with decreasing per capita income; a diminishing investment environment for job creation; and the threat of political upheaval; all of which could translate into a "massive outflow of refugees" [23].

\section{U.S. media's coverage of Haiti}

The media's depiction of Haiti and Haitians has been the subject of research over the years. I will therefore discuss the findings of some of these previous studies. This section will include a review on research on the 2004 coup, which resulted in the overthrow of Aristide; the passage of Hurricane Jeanne in the same year; coverage of the 2010 earthquake; and Black Press coverage of Haiti.

\section{Coverage of aristide and hurricane jeanne}

Potter [24] argues that the media's framing of Haiti as "a failed state" is one sided, given the external factors that contributed to the island's present state. Honing in on the U.S.' relationship with the French-speaking island over the past three centuries, Potter states: "These two countries have historically been and remain intricately connected through geography, the Haitian diasporas, and the global economy" [24]. She asserts that most of the consumers in the U.S. get their perception of the rest of the world via the media and that such negative impressions can dissuade the U.S. public from visiting, migrating, investing or opening businesses in Haiti.

In her writing, she analyzes Haitian representation in five major U.S. newspapers, namely: the New York Times, the Washington Post, the Miami Herald, USA Today, and the Boston Globe for the entire year of 2004. She notes that that year was chosen because of the island's 200th independence anniversary; the political disquiet surrounding Aristide's ouster; and the devastation caused by Hurricane Jeanne. Potter [24] employs qualitative and quantitative content analyses of more than 700 articles published in the newspapers during that time frame. The researcher specifically examines the dominant frames used in the articles, identifying them as: "violence and political unrest;" "poverty;" "history;" "illicit drug;" "landscape;" "refugee;" and "geographical frames" [24].

Potter notes that "violence" was the most-used word by all five media outlets to describe the island. Other descriptive terms often used are "politically unstable," "turmoil," and "corruption" [24]. These terms were used notwithstanding the fact that the U.S. has a hand in the island's instability and violence. In the second frame, poverty, she highlights that the press pointed the blaming finger at Haiti when addressing the island's economic situation. 
In the history frame, Potter [24] pays specific attention to the media's coverage of Haiti's 200th independence from France. While she acknowledges that the media made mention of the accomplishment, sheargues that they often framed the stories with reference to the island's present-day political hardships. Moreover, Potter [24] states that the newspapers recognized the island as the world's first black republic but the tendency were to downplay the accomplishment. The researcher then expounds on the implications race has had on Haiti. Referring to the viewpoint in the 19th century, Potter underscores that at the time, "an independent black republic was an abomination in the eyes of not only American slaveholders but also the Western world" [24]. She concedes that some articles did pay attention to the plight of Haitians, but such articles were rare.

Paying attention to the fourth frame, that of illicit drugs, Potter details what she terms as the media's exaggeration of drug transshipment in Haiti. She notes that 42 references were made by the media regarding drug trafficking, eight of which hinted that the island is a hub for Colombian cocaine headed for the U.S. Not discounting the fact that illegal drugs do, indeed, pass through Haiti en route to the U.S., the researcher stresses that the Dominican Republic only accounts for about 7 percent of cocaine bound for the U.S. In fact, Potter argues there is proof of U.S. involvement in the illicit trade. However, Arthur [25] notes that the International Narcotics Control Strategy 2001 report identified Haiti as a major hub for drug trafficking for Colombian cocaine heading for the U.S.

The landscape frame is often negative [24]. She highlights the media's constant focus on the island's environmental problems and natural disasters. In their coverage in the aftermath of Hurricane Jeanne in 2004, Potter notes that most of the articles analyzed pointed the blaming finger at Haitians for deforestation and erosion. "The overall impression of Haiti's landscape from the cataloguing of words was that of a dirty, muddy, trash-filled, mountainous, deforested country awaiting its next human-made disaster" [24]. These reports, she argues, are in spite of the fact the French leeched the soil for the production of sugar cane during the colonial period. She then points to the U.S.' role in the island's current landscape, noting that during the Occupation "monoculture" and "extensive agriculture practices" were employed [24].

In her analyses of the final two frames, refugee and geographical, Potter respectively claims that the media often used the terms "boatloads" and "mass boat migration" and that they consistently failed to relate Haiti's problems with regards to interference by other countries. In the former, the scholar purports that the media's focus on refugees was owing to the assumption that the coup in 2004 would cause many of the islanders to leave the country via boat. This, in turn, fueled news consumers' "anxiety that the United States would be overrun by 'boat people' in their 'flimsy boats"' [24]. The author sums up her findings by saying that U.S. media's portrayal of Haiti and Haitians falls in line with its (the U.S.) immigration policy. "Haiti's geographical frame, which establishes the country as the political, economic, and environmental wreck of Western Hemisphere, set out to justify U.S. policy toward Haiti” [24].

Baumgartel [26] also examines the coverage of the 2004 coup in Haiti. However, her research focuses only on coverage by the New York Times and the Washington Post. Her analysis of the coverage spans the three-week period leading up to the coup on February 29, 2004. She creates seven categories of terms used to describe Aristide's opponents and proponents, namely: "gang," "thug," “mob," "protester," "militant," "force" and "group" [26].She deems the former three as negative; the two that follow are seen as positive; while the latter two categories are perceived as neutral.

The findings reveal a slant in the newspapers' coverage in favor of Aristide's opponents [26]. "Aristide's supporters were referred to in the articles using negative value words in over $35 \%$ of cases, while opponents of Aristide received negative references in only $14.5 \%$ of cases" [26]. Words that could be interpreted as carrying a value judgment had a frequency of 45 percent for the former president's supporters, while value judgment terms used for his opponents were recorded at only 26 percent.

The coverage given by both the New York Times and Washington Post generally leaned to the negative side in the representation of Aristide's supporters [26]. According to the researcher, Aristide's adherents were described using negative connotations nearly 20 percent more frequent than non-supporters. The writer translates her findings as proof of the media's inclination to follow an elitist agenda. She purports:

"Given the Bush Administration's attitude towards Aristide, my evidence supports the argument that the US mainstream media often acts as a mouthpiece for US foreign policy. These types of representations do little to foster nuanced understandings of international politics or comprehensive information for U.S. American readers and international readers alike" $[26]$.

Baumgartel [26] argues that the media's dominant coverage of Aristide as a presider over human rights abuses is highly inflated. She challenges the U.S.' pro-democracy stance, stating that the coverage by the media reflected the U.S. government's foreign policy goals more than democratic ideology. "Haiti under Aristide serves more to exhibit what is not democracy, than what democracy can or should be, according to U.S. media coverage" [26]. Reeves [22], on the other hand, notes that the media failed to pay attention to political violence by the opposition in Haiti at the time. Citing the massacre of Aristide supporters in rural areas such as Gonaives in the 1991 coup, Reeves [22] highlights that minimal to no attention was given to the incidents.

However, Wucker [20] highlights Aristide's failure to end attacks that were plotted by his supporters. He was highly criticized by the international community for violence against his non-supporters. Wucker [20] specifically mentions the killing in April 2000 of a journalist at Haiti Inter Radio, Jean Dominique, who once supported Aristide but was killed after he became a critic. Aristide was adamant in his refusal to have justice served on the killers.

Lule [27] also analyzes the mainstream media's coverage of Aristide. He employs Burkean analysis of Larry Rohter's-of the New York Times-coverage of the former Haitian president from July 1, 1994 to February 29, 1996. He notes that Rohter, experienced in international affairs, took over as Caribbean correspondent to replace the then correspondent Howard French, after protestors voiced their unhappiness with French's anti-Aristide reports.

Four categories emerged in his findings, namely, "the delegitimation of the de facto government; the approbation and then disapprobation of Aristide, the avoidance of U.S.-Front for the Advancement and Progress of Haiti (FRAPH) ties; and the degradation of Haitian life" [27]. Expounding on the first category, Lule states that Rohter focused on the killings and other types of violence by the military junta. Rohter also condemned the group and "he reported with almost satisfying detail the humiliation of junta members as they were forced into exile" 
[27]. These stories came at a time when the U.S. was trying to re-instate Aristide.

However, once Aristide returned to office, the "approbation and disapprobation" of the leader soon emerged in Rohter's writings [27]. The researcher observes that initially, the former Haitian president was portrayed as the hero "who would come back to save the devastated nation" [27]. Then, once Aristide refused to welcome the U.S.' economic and security policies, Rohter began to undermine the former Haitian leader's judgment and political approach. Aristide was wary of foreign ownership of the telephone and electric industries in Haiti, but Rohter's stories "embraced the necessity of privatization" [27]. "As disagreements intensified between Aristide and U.S. officials, the disapprobation in Rohter's reporting increased" [27].

Regarding the reporter's avoidance of the U.S.-FRAPH ties, Lule [27] notes that the group began in September 1991 and that its members were the descendants of Duvalier's tontonmacoutes. Apparently, the researcher explains, the man at the helm of FRAPH, Emmanuel "Toto" Constant, was on the CIA payroll. Nonetheless, the reporter eschewed the possibility of the U.S.' link with the FRAPH. Additionally, the reporter's coverage of Haiti included degrading Haitians. "The poorest in the Western hemisphere; a life expectancy of 56; 70 percent of children malnourished; an illiteracy rate of almost 70 percent" were among the descriptions used by the reporter to classify Haiti and its people [27].

Concluding his research, Lule [27] argues that Rohter's reporting was in line with U.S. foreign policy. "Even as the policy shifted courserejecting the junta, warily restoring Aristide but insisting that he accept U.S. policy-so too did the reporting" [27].

Conversely, Downie and Revah [28] critique Aristide government's availability to the international media after his 1994 return to office. Unlike the Haitian military, Aristide's administration "alienated" the foreign media [28]. In their analysis, Downie and Revah [28] describe the Aristide government's manner of dealing with the press, at the time, as "problematic at best and arrogant at worst" [28]. Lamenting the bureaucratic red tape which journalists had to undergo, Downie and Revah [28] note that requests by foreign journalists for simple government information usually resulted in a 24-hour waiting period. Among the other concerns identified are the refusals of government spokespeople to verify information reporters requested and for secretaries to hang up telephones on journalists.

Beeton [29] chronicles what he sees as a lack of context in the mainstream media's coverage of the Caribbean territory. To carry out the first phase of his study, the writer interviewed U.S. journalists who have worked the Haiti beat. Beeton highlights one of the reporters' comments: "Everyone knows the place is a mess, so what are you going to tell me thats new?" [29]. This "lack of editorial interest" as Beeton puts it, has resulted in the press' failure to cover many acts of violence against innocent Haitian people by the United Nations forces, the Haitian National Police (HNP), and death squads.

The researcher conducted a search on Nexis for the July 6, 2005 incident in which UN troops were said to have fired some 22,000 shots, killing 30 people [29].He underscores that slightly more than 12 U.S. newspapers mentioned the incident for the month of July; and when the press did run stories on the occurrence, they were "short newswire briefs" [29]. "These items typically described the incursion as an example of the UN mission's success in its stated goal of eliminating gang members, ignoring civilian deaths" [29].
Shortly after Aristide's second ouster in 2004, the HNP accompanied "dozens of machete-wielding men" and "hacked and shot at least six people to death" [29]. Beeton notes that only six U.S. papers printed articles on the incident.

Juxtaposing the reports on crimes following the 2004 coup d'état against the amount of coverage given to three years in Aristide's second term, Beeton [29] finds a difference. Noting that the reports on Aristide far outnumbered those after his exit from office, the researcher states that numerous articles and editorials condemned alleged Aristideled acts of violence in Haiti. However, "some of the supposed statesanctioned violence described in the U.S. news later turned out to be fabricated" [29].

Beeton concludes: "The attention paid to the Aristide administration and many allegations of human rights abuses during that period that have not stood up to scrutiny, underscores how little attention Haiti has received even while some of the worst abuses in Haiti's modern history have been committed" [29].

\section{Coverage of the 2010 earthquake}

Ulysse [6] examines CNN's coverage of the 2010 earthquake. She specifically references a January 22, 2010 episode of Anderson Cooper 360 in which the anchor appeared on air with correspondent Karl Penhaul. According to Ulysse [6], Penhaul recounted to Cooper an incident in which a Haitian woman lost two children in the quake and reportedly told Penhaul that she "threw them away" [6]. However, the researcher notes that the reporter took the statement out of context because the woman was, in fact, saying that the children were thrown in a mass grave by others and therefore, she wasn't able to bury them. Ulysse sees this finding as a "dehumanizing," "callous" and "indifferent" portrayal of the Haitian people [6]. "It stems from the dominant idea in popular imagination that Haitians are irrational, devil-worshipping, progress-resistant, uneducated, accursed black natives overpopulating their God-forsaken island" [6].

Most recently, a media advisory was published by Fairness \& Accuracy in Reporting (FAIR)-a non-profit organization that denounces and documents media bias-on the coverage given to the return of Duvalier and Aristide. In the article, the group criticizes the media's likening of the two leaders [30]. FAIR condemns the media's equation of the two, noting that Aristide was a duly-elected president, whereas Duvalier was a despot. The non-profit organization identifies columns in USA Today, Sun Sentinel, the New York Times, and the LA Times as elements of the mainstream media that likened the two leaders. As a suggestion to journalists, the media advisory asserts: "One would hope reporters could find a way to make a meaningful distinction between a ruthless, bloody dictator and a popular elected president" [30].

\section{Studies on the Black Press' Past coverage of Haiti}

Scholarship on the Black press' coverage of Haiti is limited. However, Suggs [31] conducted a historical study on the articles and editorials published by the Black press during the U.S. occupation of Haiti. The results of this research show a difference in the reporting of Haiti when compared to that of the main stream media. Specifically referencing Baltimore's Afro-American Ledger, the writer notes that in its editorial "Bullying Haiti," the publication accused the U.S. of using Haiti to "demonstrate the military preparedness of its Atlantic fleet" [31].

Additionally, the Black press thought the end of World War I 
would translate into the end of the occupation [31]. However, President Wilson was unable to withdraw troops because of the ongoing "guerilla war" with Haitian revolutionaries. Consequently, Black press such as the Afro-American Ledger, the Cleveland Gazette, The New York Age, the Washington Bee, and so forth, portrayed the Haitian revolutionaries in a positive light. "The press's objective was not only to report the news but to sensitize America to the racism, brutality, and the economic exploitation of Haiti" [31].

Suggs [31] adds that the Black press joined forces with the NAACP to put an end to President Wilson's foreign policy towards Haiti. However, the Black press' low circulation figures and their "inability to attract the masses" compromised their overall impact [31]. Then, when Hoover became president in 1929, papers such as the Chicago Defender, and the Pittsburgh Courier wrote extensively on the problems Haitians faced during the occupation. With headlines such as "Trouble in Haiti," "Marines Murder Haitians," and "U.S. Policy in Haiti Criticized by Congress" the Defender published their anti-American occupation sentiments [31].

Even with the 1931 adoption of the U.S.' new policy of Haitianization, the Black press still published dissenting information [31]. According to the author, the Courier began their editorials with headlines such as "Haitian Home Rule Still Idle," and "Get Out of Haiti" [31]. The press, Suggs notes, believed that the new policy would only extend the U.S.' rule over Haiti.

It was not until the withdrawal of the U.S. troops in 1934 that the black press' stories on Haiti were positive [31]. He notes the Courier's article in which the newspaper highlighted that 50,000 Haitians were cheering with the lowering of the American flag. The writer concludes his historical analysis, saying: "And throughout the United States' occupation of Haiti, the press was determined to speak because, in the words of the first African American newspaper, Freedom's Journal, 'others have spoken for us too long" [31].

Walker's [32] analysis-of the roles mainstream and ethnic media play in the acclimatization of the Haitian diaspora in Miami-adds to the limited body of research on ethnic media coverage about Haiti and Haitians. Heposits that Haitian media helped Haitians, who were living in Miami for less than a year, adapt only in cases where the ethnic group consumed other U.S. media. His conclusion is based on results from interviews with immigrants and content analysis of the Haitian radio stations and newspapers in Miami at the time of the study. Among Walker's key findings are that some of the Haitians used ethnic radio programs to help them learn basics about the way of life in Miami; and to learn English. However, the Haitians generally agreed that most of the Haitian newspapers in Miami focused on Haiti and therefore did not provide much information which could help the diasporas to adapt to Miami life. The researcher also concludes that Haitians who used both ethnic and mainstream media tended to have better communication skills and were more adapted.

\section{Ethnic media}

Present-day scholarship about ethnic media's coverage of Haiti is necessary, especially given the "fast-paced growth of ethnic, minority and diasporic media" over the years [4].

Deuze's [4] article gives insight into the difference between ethnic/minority media and the mainstream. According to Deuze, ethnic media's embrace of participatory/community-driven practices "disrupts the very fabric of contemporary (Western, national) society" [4]. Furthermore, the Black Press is a medium through which “oppositional meanings" are communicated [33]. Huspek argues that the Black Press transmits meanings that are contrary to those reported by the dominant/White press.

However, Shi (2009) argues that news coverage by ethnic media can, at times, mirror that of the mainstream. Additionally, media that is alternative to the mainstream often stray away from the "dialogical" practices that are supposedly characteristic of non-mainstream media [34]. Shi contends that ethnic media do not always give an alternative voice to reports in the mainstream. Her work focuses on Chinese media in the U.S., examining the discourses of the Chinese-American papers Sing Tao Daily and the World Journal and their readers from July 2003 to July 2004. She notes that the newspapers' commercial-driven nature limits their alternative factor. As a result of the press' financial dependability, reports on issues in the Chinese community such as race, class, and gender-related matters are often limited or overlooked. Shi therefore contends that "ethnic media in general should not be interpreted solely in opposition to mainstream media" [35]. Cottle [36] also speaks of the tug-of-war, so to speak, that ethnic media face between financial opportunities and expectations from the community they serve.

Another possible threat to the alternative factor of ethnic media is posed with the trends of ethnic media ownership today. Matsaganis et al. [37] highlight that ethnic media outlets are often acquired by the mainstream. "As mainstream media organizations continue to look for ways to expand their markets, some explore opportunities to partner with or acquire successful media ethnic media operations" [37].

\section{Theoretical Framework}

I will now detail theories that can be applied to U.S. media coverage of Haiti. Herman and Chomsky's Propaganda Model and Fanon's Black Skin, White Masks will be explored in this section.

\section{Propaganda framework}

Herman and Chomsky's [38] propaganda model is a helpful analytical tool for understanding the mainstream media's reports on Haiti. The model shows the mainstream media's tendency to follow the agenda set by the government and other elitists in society. The propaganda model purports "that the societal purpose of the media is to inculcate and defend the economic, social and political agenda of privileged groups that dominate the domestic society and state" [38].

Herman and Chomsky [38] propose that five filters of news-size and concentrated ownership of the dominant media firms, advertising, sources, flak, and anticommunism-determine what goes into the news and how the news item is reported. Particularly, Herman and Chomsky explain that the media's mutual relationship with government shapes the content of the news. The researchers note that the government facilitates the news-gathering process through its issuances of press releases, speeches, reports, as well as through press conferences. Owing to the nature of the relationship between the media and the elite, Herman and Chomsky purport that the media may avoid reporting dissenting information. While journalists often aim to be objective in their reporting, the "enduring value" of "ethnocentrism" challenges objectivity [1]. The ethnocentric value in news is especially evident in the media's tendency to cover foreign news through the lens of "American practices and values" [1].

Although the propaganda model was published in 1988, Herman and Chomsky, in a 2009 interview, maintain that the model remains an applicable analytical tool of the media. They note, "Reducing the 
relevance of the Propaganda Model has so far proved a very difficult task" $[39,40]$. Klaehn [41] concurs stating that the Propaganda Model can be applied to a wide range of topics and that its applicability is dependent upon researchers' ability to recognize its versatility.

\section{Black skin, white masks}

Frantz Fanon's Black Skin, White Masks focuses on the "inferiority complex" that exists for blacks in society because of colonialism [41]. He uses this complex to explain a world in which white is superior and black is subordinated. As he states: "For the black man there is only one destiny. And it is white" [41]. Owing to this feeling of inferiority, blacks often behave in ways that would make them closer to whites. For instance, Fanon points out that, in the presence of white men, blacks behave differently than when they are around other blacks. Ashamed of the negativity and darkness that has been associated with being black; the blacks figuratively cover their faces-their black skins-with white masks.

However, he explains that blacks must remain inferior in order for whites to maintain their status. "Every colonialized people-in other words, every people in whose soul an inferiority complex has been created by death and burial of its local cultural originality-finds itself face to face with the language of the civilizing nation; that is, with the culture of the mother country" [41]. Thus, through colonization, the white man's imperialism makes him superior to the colonized; the white man is able to impose his world view on the colonized people.

\section{Methodology}

In this chapter, I will identify and expound upon all the steps that were taken to access, collect, and finally analyze the data used for this research.

\section{Method used}

I employed narrative analysis to examine the mainstream and ethnic media's coverage of Aristide. Through narratives, the audience is able to see the world from a certain perspective; through analysis of these stories, critics are able to identify the stance presented in the narrative and explore the chances that the audience would conform to the narrative's perspective [42]. The time frame for this study is 19912011.

\section{Sampling and data collection procedures}

Black Press' coverage of Aristide: I searched four different databases in order to generate articles from the Black Press. Articles from ethnic media are limited, hence the reason forth search on several databases. The time frame of 1991 to 2011 was used because Aristide was elected president in 1991 and he has made headlines in the U.S. from then until the present. Each database was searched using the keyword "Aristide." Eliminations were made, including articles that were less than 150 words, any results that were deemed irrelevant (Haiti was not the main topic), wire articles and blogs.

The first data source was the website of nnpa.org, which lists the National Newspaper Publishers Association's African-American newspapers in the U.S. I searched every newspaper listed. Following the said eliminations, 18 articles remained.

The second source of articles came from the database Proquest, which initially produced 37 articles, 15 of which met my criteria.

The website of New America Media-an association website of ethnic media organizations-was the other data set used. An initial search yielded 100 articles. Two articles met my criteria.

The final source of articles was The Root, an online source of news owned by the Washington Post reporting African-American news. Initially, the search yielded 41 results, with one article meeting the criteria.

Therefore, a sum of 36 articles was used for the analysis of the Black Press' coverage of Aristide.

\section{Mainstream media's coverage of Aristide}

For the mainstream media section of the research, a LexisNexis search was conducted for 1991-2011 for major newspapers using the same criteria and keyword. The search yielded 997 results. I decided to analyze 36 articles so that this would be the same number of articles as the Black Press. Random.org was used to generate 36 articles. If the article did not meet the specified criteria, or was not American based, it was not used. Using this process, I selected 36 articles.

\section{Data analysis procedures}

As mentioned, narrative analysis was used. To employ narrative analysis in research, the researcher can examine the setting, characters, narrator, events, temporal relations, causal relations, audience, and theme of the narratives [42]. However, based on the questions posed in the research, "the critic's task is now to identify which of those features are of most significance and relevance to the research question the critic is asking" [42]. With this in mind, I deemed the characters and themes most relevant to the answering of the research questions. (See Appendix A for code sheet).

Characters: The following questions were asked for the analysis of characters:

1. How was Aristide portrayed in the article? (a) Was Aristide depicted as causing problems? (b) Was Aristide depicted as solving problems?

\section{Who are the sources?}

Themes: Foss [43] notes that a theme is an overall meaning of a narrative. The answers for the aforementioned questions were then used to determine the answer to the subsequent question:

\section{What were the major themes of the articles?}

\section{Limitations}

As is the case with all research methodologies, narrative analysis is not limitation-proof. Hanson (1999) identifies three limitations associated with the use of narrative analysis-the method isn't suitable for all news articles; its effectiveness is dependent upon the researcher's writing and analytical abilities; and the inherent paradox. Nonetheless, the scholar underscores the positive attributes of the research method. "It can lead us to insights on the limitations of a particular story line, and on the way we tend to simplify the world" [43]. Hanson notes that narrative analysis is a "powerful tool" in the analysis of "fiction, oral traditions, jokes and urban legends, advertising, public relations campaigns and news presentation" [43].

Being relatively new to research poses a limitation. Also, the research is limited to the media outlets included in the corpus. All mainstream and Black Press were not analyzed, therefore generalizations cannot be made. 


\section{Credibility/trustworthiness}

To ensure that the results are credible, I followed the established guidelines for conducting narrative analysis. Also, I tried not to over analyze the articles. This was to lessen the likelihood of another person conducting the same research and yielding completely different results.

\section{Findings}

From my narrative analysis of the characters and themes, it was found that the Black Press' depiction of Aristide was primarily as the savior of the poor Haitians, as a corrupt politician, and as a victim of U.S. foreign policy. As for the mainstream press 'coverage, he was mainly depicted as savior of the poor, and as a corrupt politician.

I will now detail my study on the characters and themes to explain the results. The major themes used in the Black Press' coverage will be explored, followed by the major themes used in the mainstream's coverage. Comparative analyses of the two types of media coverage will be made.

\section{The Black Press' coverage of aristide}

The overall analysis revealed that Aristide was often depicted as the savior of poor Haitians, but he was still identified as corrupt. The Black Press also showed a willingness to report information that is contrary to that reported by the mainstream. Notable in this study is the finding that the Black Press overtly identified the U.S. as the cause of Aristide's/ Haiti's problems.

\section{Aristide is the savior of poor Haitians}

This theme was supported by the depiction of Aristide as bringing democracy to Haiti. He was portrayed as a politician who had the poor at heart, fighting the dictators for the interest of the impoverished masses. For example, in one commentary article published by Final Call, the writer depicted the former Haitian president as "an enormously popular Roman Catholic priest working among the poor and against the brutality of Haiti's dictators" [44]. This article was written at the time of Aristide's second ouster. This shows that despite the controversy surrounding him and his exile at the time, the writer still saw him as a vital figure in fighting for ordinary people.

Another writer, this one from NNPA, referred to the then Haitian president as a source of inspiration for downtrodden Haitians. In his editorial, the writer said.

"Jean-Bertrand Aristide captured the imagination and aspiration of the people like no other leader in modern Haitian history. $\mathrm{He}$ personified the desire and will of the Haitian poor, peasants, workers and forward-looking people from all sectors to transform the nation into a participatory democracy with a vibrant economy. Aristide had the capacity to inspire the dispossessed to believe a brighter future was possible with their engagement" [45].

These statements were made at a time when Aristide was still in exile in Africa, six years after his second ouster. Yet, the sentiment was similar to those expressed in 2004, reinforcing the theme that Aristide is the best man for liberating the poor in Haiti.

The theme of Aristide as a savior depicted him as the legitimate voice of the poor and was supported in the frequent use of Aristide as a source. He was quoted and paraphrased quite often in the various articles from the Black Press. In a 1994, while Aristide was still in exile, he was speaking in California. He was quoted by an Oakland Post writer, Charles Aikens saying.
"LOVE, is the name of God. How can the U.S. Government welcome Cuban refugees and send back Haitians, unless it is a racist policy? In Haiti, we have a house on fire. With the American Coast Guard sending back refugees to a house on fire; it's a crime" [46].

Again, the former priest was portrayed as advocating for the rights of the poverty-stricken Haitians who had fled Haiti to escape the brutality that existed under the military junta at the time.

He was credited as starting democracy in Haiti, so much so that an election without his party, FanmiLavalas, was deemed as an election that goes against the masses. To bring across this point, one writer's lead sentence read:“To cut to the chase, no election in Haiti, and no candidate in those elections, will be considered legitimate by the majority of Haiti's population, unless it includes the full and fair participation of the Fanmi Lavalas Party of President Jean-Bertrand Aristide" [47].

Aristide was not in Haiti at the time, yet his party was still seen as one which must participate in the elections for fairness and balance. Therefore, despite being thousands of miles away from Haiti at the time, the great impact that Aristide had on saving Haiti was still reflected in the narrative. The writer then continued with statistics, noting that since Aristide won by a 67 percent majority in 1990. This drives home the writer's point of Aristide's popularity and the importance of his party to the Haitian people.

To reinforce the idea that Aristide can save Haiti through democracy, Sun Reporter coverage quoted Oakland Congresswoman Barbara Lee expressing displeasure about Aristide's 2004 ouster and the U.S. government's support of the coup. Once again, his necessity in Haiti was highlighted when she said: "I am outraged that the democratically-elected President of Haiti, a country where a true democracy has recently emerged after decades of autocratic rule, has been pushed out by an administration anxious to get rid of him" [48].

Lee's statements consolidated the idea that Aristide was necessary for democracy in Haiti. This view of him being necessary for democracy stems from the broader picture of him being the leader in Haiti who represented the poor Haitians who were oppressed during "decades of autocratic rule" [48]. This relates back to the theme of Aristide as the president who saved poor Haitians from autocracy.

All but one article studied had information that either explicitly or tacitly depicted Aristide as someone who should be given the right to return to Haiti because of his history of addressing the needs of the underprivileged. Seven years later, articles continued to rally for his return. For example, in an NNPA article, writer Bill Fletcher Jr. underscored that Aristide should be allowed to return to Haiti because of the essential role the politician played in paving the way for democracy in Haiti. "Aristide remains the most popular leader in Haiti and his party, despite myriad of internal problems, remains the most significant and grounded force in the country" [49].

After his 2011 return, coverage confirmed his ability to save Haiti through its depiction of the large crowd of Haitians who welcomed him upon his return. One Final Call writer described the crowd as "thousands of jubilant supporters" who were "chanting his praises and waving his portrait and Haitian flags as if he was a candidate in the presidential runoff election" [50]. This description illustrated the effect Aristide still had on the Haitian masses.

\section{Aristide is corrupt and causing problems in Haiti}

Contrary to the savior theme, other articles contained information, 
in varying lengths, characterizing Aristide as the root of Haiti's problems. In these articles, Aristide was identified - whether through the writer's commentary, or historical information, or sources-as both causing and contributing to problems.

In a Sun Reporter article, the writer stated that Aristide's leadership partly helped to worsen poverty in Haiti. The writer stated: "The combination of Aristide's governing flaws and U.S. economic opposition meant that the poor did not improve their situation under Aristide" [51]. While Malveaux [52] did not completely blame Aristide for Haiti's worsening poverty, he suggested the ousted leader contributed to furthering poverty.

The Haitian politician was also depicted as an individual who advocated and practiced violence against his opponents. For example, a Final Call article noted that "moderate civilian opponents to the government (Aristide's government) have been prevented from holding peaceful protests by Aristide supporters who have stoned marchers and erected burning barricades to block proposed demonstration routes in the capital" [52].

In another article, this one by The Broward Times, the writer Raymond Joseph denounced U.S. Senator John Kerry's statements that Aristide is a victim of the Bush administration. Criticizing John Kerry's statement, the writer rhetorically asked "Is Kerry aware of the gangs that Aristide organized that became notorious for harassing, intimidating, and even killing his opponents" [53].

The politician's alleged link to corruption was made evident in articles that included allegations of his misappropriation of public funds and fraudulent elections. In the same article, Joseph referenced a Wall Street Journal story which reported that hundreds of thousands of dollars was found in Aristide's basement.

"How can Aristide's defenders explain \$350,000 rotting in the president's basement while his partisans in Cite Soleil live in abject poverty? Could the millions of dollars spent officially by Aristide on lobbyists and friends in America have any bearing on the pro-Aristide stance of people who should know better?" [54].

Joseph then went on to note that the 2000 election of Aristide as president was fraudulent because only 10 percent of voters turned out to cast their ballots.

The former president was also characterized as a leader who was power-hungry and one who was only looking out for the interests of his supporters. Professor of Sociology at Wesleyan University Dr. Alex Dupuy, was quoted by Final Call saying:

"Aristide at one point may have been the champion of the masses, but he's long ceased to be that...Aristide is basically out to maintain himself and his supporters and his allies in power, and to enrich themselves in the process, rather than to really respond to the interests of the masses of the population" [52].

In a similar article by the Broward Times, another writer said: "Following his stunning victory, Aristide created the Lavalas (meaning "flood") Family Party, but was so greedy for power, he alienated most everyone in it; they deserted and created their own factions" [39]. The 2011 news stories still portrayed the twice exiled president as corrupt. Several articles included information that referenced Aristide's alleged involvement in the murdering of Haitian journalists and opponents. While these alleged incidences happened several years prior to 2011, the information was still included. This shows that although time had elapsed, a part of the Black Press' frame of reference for Aristide had very much to do with historical portrayals. In an article from The Root, for example, the writer Dreyfuss [55] was sure to underscore that the former priest was "increasingly linked to corruption" [54].

\section{Aristide is the victim of U.S. foreign Policy}

Some of the articles linked Aristide's/Haiti's problems to being partly caused by the U.S. While this was a small number of articles, the finding shows the Black Press' tendency to report information that challenges the U.S. government.

\section{In a Final Call article, the writer emphatically said:}

"The coup that overthrew Pres. Aristide, a coup that had the clear blessing of the Bush administration, has been responsible for plunging Haiti into a nightmare of violent repression, stories of stories of refugees' attempts at escape, government incompetence in the face of political calamities, all shrouded in a deafening silence in most U.S. media" [55].

Sun Reporter writer Malveaux lamented that the U.S.' blocking of much-needed aid to Haiti crippled the Haitian economy. "The United States position has been antagonistic to the Aristide administration for quite some time. We blocked a $\$ 500$ million World Bank loan that would have alleviated the material suffering and poverty that so many Haitians experience" [51].

Malveaux [52] also said that the then Secretary of State Colin Powell dismissed allegations that the U.S. was somehow involved in Aristide's ejection from office. In response to Powell's denial of the accusations, Malveaux [52] emphatically stated: "If you believe George W. Bush and Colin Powell when they talk about weapons of mass destruction, then you might as well go on and believe them now when they talk about what happened in Haiti. But if you learned your lesson last time, then there ought to be at least reasonable doubt about anything they allege" [51].

In 2011, his then imminent return was depicted as potentially having a negative effect on the runoff presidential elections. For example, a Washington Afro article noted that the U.S. government was "wary" of Aristide's return plans out of concern that "his homecoming could upset the country as preparations are being made for a run-off election in March" [56].Counter to this theme, an Afro-American Newspapers article, published after the runoff elections, reported that fraud caused a delay in the first set of election results. However, the writer then went on to cite $\mathrm{CNN}$, stating that Aristide's "presence did not appear to disrupt the election process" [57]. The fact that CNN deemed the ousted leader's presence as causing no apparent disruption raises the question of whether or not the Obama administration's concerns had merit. This shows that not all stories were in agreement with Aristide as a problem.

Emphasizing U.S. undermining of Aristide, Dreyfuss [55] noted in his article:

"Ten years after Bill Clinton had praised him as Haiti's best hope for democracy, Aristide was suddenly a pariah, flown secretly out of the country and dumped in central Africa without finishing his term of office" [54].

Also, in a Final Call article, the writer quoted Co-Director of the Center for Economic and Policy Research in Washington D.C. Mark Weisbrot saying: "The United States has been the prime cause of instability in Haiti, not only over the last two centuries, but the last two 
decades. Although Haiti is a small and poor country, Washington still cares very much about who is running it" [58].

\section{Sources used}

The main sources used by the Black Press reinforced the various themes. The pro-Aristide sources expressed sentiment that depicted him as a savior of the poor and the victim of U.S. foreign policy, and the anti-Aristide sources contributed to the corrupt politician theme. While U.S. government officials were used as sources, the Black Press often used Haitian officials and proletariat Haitians as sources as well. Some of the U.S. sources often used were Bush administration officials, Clinton administration officials, members of the Congressional Black Caucus (CBC), and U.S. university professors. Aristide supporters, his adversaries, and Haitian government officials were among the most commonly-used Haitian sources.

\section{The mainstream press' coverage of aristide}

Like the Black Press, the mainstream's past coverage depicted the former priest as a savior of poor Haitians, and as a corrupt political figure. The only major difference between these results and the Black Press was that the mainstream seemed unlikely to identify Aristide as a politician who was a victim of U.S. foreign policy.

\section{Aristide is the savior of poor Haitians}

This God-like way of depicting Aristide, so to speak, was evidenced in numerous articles. A 1994 Houston Chronicle article epitomized this theme. In it, the writer R.A. Dyer quotes Haitians who were ecstatic as they waited for Aristide's 1994 return from exile. One Haitian was quoted saying: "He is like Jesus for us. In Haiti, Aristide is second only to God. He is the only hope for Haitians." Another Haitian said: "His words prick me like a knife. It is because I know that he is the only person who can help the Haitian people. Since he has come back, there is hope"[59]. These statements by the Haitians showed the extent to which Haitians adored and praised Aristide. The comments were often complemented with vivid descriptions of the celebrations. For instance, in a 1994 New York Times article the writer Catherine Manegold's lead read: "At the moment of the Rev. Jean-Bertrand Aristide's arrival today every step suddenly became a dance step, every side street a direct route to the palace, every car and truck and jeep a parade float jammed with people, and every crowd a wild, gyrating, single voiced celebration" [60].

Manegold's detailed portrayal of the scene in Haiti at the time of Aristide's arrival demonstrated to readers the great impact the ousted Haitian president had on the people.

In a Philadelphia Inquirer article-in which Aristide was portrayed as a welcomed change from Haiti's negative situation-[61] quoted a Haitian teenager who said his return "symbolizes change and a removal of all that was bad, including the former government" [61].

Years later, in an article from the New York Times, Aristide was still portrayed as concerned with helping Haiti. Noting the reason given by Aristide's lawyer for his 2011 return, the article read: "Asked why Mr. Aristide wanted to return, Mr. Kurzban said, 'He wants to return as a private citizen, to help his country"' [62].

In an article about the former president prior to his 2011 return, a Washington Post writer described him as a "revered figure among Haiti's poorest" [63]. Miroff [64] continued the narrative with a description of comments a Haitian woman made about Aristide's return.
"Louis said she was given a shovel this morning and asked to help spruce things up for the arrival of the man many here simply referred to as 'Father.' She said she didn't care that Aristide wasn't on Sunday's ballot and wouldn't be returning to office. 'We want to give us jobs,' she said" [63].

Continuing the explanation of the scene in Haiti as Haitians awaited Aristide's arrival the writer added:

"Down the road at the headquarters of Aristide's Foundation for Democracy, workers were sweeping the floor of the vast auditorium where he once gave speeches and sermons. Plastic flowers were laid out on the stage, and one woman with a broom began singing despite the huge clouds of dust being kicked up into the air. 'Stay away from evil,' she called out, "Today is our day to be delivered" [63].

\section{Aristide is corrupt and causing problems in Haiti}

A majority of articles depicted him as corrupt and causing problems in Haiti. He was depicted as someone who brought disorder to society by inciting violence and hatred against his opponents; someone who was responsible for the death of many Haitians.

The Oklahoman depicted Aristide as a politician who used gangs to "intimidate the opposition" [64], and in a Palm Beach Post article, the writer noted:

"Jean Ronald Register is in hiding. His life has been threatened by some of the scarier people in the hemisphere: Haitian street gangs known as chimeres-ghosts or monsters-who are aligned with President Jean-Bertrand Aristide [65].

In another instance of negative portrayals of Aristide, a Virginian Pilot writer described a 'necklacing' death-igniting a gasoline-filled tire around a victim's neck-of Sylvia Claude, a Haitian who was a staunch anti-Aristide politician. "Aristide has approved of 'necklacing' and prominent members of his government-in-exile are seen standing in the crowd watching Claude's death" [66].

Another instance of Aristide's alleged cruelty against his opponents was depicted in a Washington Times article in which the writer Bill Gertz blamed the former leader for the death of several Haitians in 1995. "At least six persons were killed in mob violence that erupted November 11 after an angry speech by Mr. Aristide at the funeral of a cousin who was gunned down, presumably by the president's opponents" [67].

A 1994 Washington Post article highlighted that lawyers and business people in Haiti see Aristide as bringing "anarchy, chaos, and destruction" to Haiti [68]. In the same article the writers added that the Roman Catholic Church accused Aristide of "incitement to hatred and violence" [69].

Other scenarios in which Aristide was depicted as corrupt/causing problems include: his failure to adopt President Rene Preval's freemarket policy that was designed to help Haiti out of its poverty [70]. $\mathrm{He}$ was also partly blamed as a possible reason why international countries kept funds from Haiti. For example, one Atlanta Journal \& Constitution writer, Williams [71] noted that the allegations of corruption and human rights abuses charges could explain the unwillingness by the international community to disburse aid monies to the country.

Another prime illustration of Aristide as someone who did not have Haiti's best interest at heart was expressed in a Washington Post article in which the writer said that Aristide lived lavishly in Washington (in 1993) from Haitian funds while Haitians were jobless. 
By juxtaposing Aristide's lifestyle with the job crisis in Haiti, the writer Lally Weymouth, depicted an inconsiderate and self-serving Aristide.

"While Aristide lived nicely in Washington-enjoying access to thousands of dollars in frozen Haitian assets made available to him by the U.S. government-Haiti, already the poorest country in this hemisphere, saw the loss of thousands of jobs as companies in electronic assembly, clothing manufacture and other light industry sold out to Haitian businessmen of moved operations elsewhere" [71].

Eighteen years later, the same narrative of Aristide as a problem causer was observed. In a New York Times article, the writer underscored Washington's concerns about his 2011 return.

"The United States and several other countries, including France and Canada, which provide millions of dollars in support to Haiti, the western hemisphere's poorest country, have expressed concern that Mr. Aristide's return could destabilize the country as it struggles to resolve a hotly contested presidential election" [62].

A Washington Post article specifically noted the concerns President Obama had with Aristide's 2011 return. "U.S. officials have been so worried about Aristide's disruptive potential that President Obama spoke with South African President Jacob Zuma this week to express his concerns, according to the White House" [63]. Noting that the 2010 presidential elections in Haiti were "marred by fraud and chaos," the writer said the "fragility has foreign observers and many Haitians wary of Aristide's return so close to election day" [63].

Miroff [64] also challenged Aristide's claims that the aim of his 2011 return was to help the country's education sector. Implying that the former president had an ulterior motive in his return, the writer wrote: "Aristide has said he will stay out of politics and wants to return to teaching. But few believe him-not his supporters and certainly not his adversaries" [63].

Also expressing doubts about Aristide's true intention for his return, a New York Times article added:

"Both Mr. Duvalier and Mr. Aristide claim that they are interested in reconciliation; both are doubted by critics of their governments. Experts inside and outside Haiti fear that the presence of the two former leaders could further destabilize the country, which is already struggling with cholera, tent cities created by last year's earthquake and political instability before the delayed presidential runoff on March 20" [72].

Cave et al.[73] continued by quoting Jon Piechowski, spokesman for the American Embassy, saying:"What Haiti needs right now, coming out of a prolonged first round of elections, is a period of calm, not divisive actions that can only distract from the vital task of forming a legitimate and credible government' [72].

\section{Sources used}

Like the Black Press, the mainstream made use of sources that reinforced the themes of the narratives. U.S. government officials and Haitians were often quoted and paraphrased. However, fewer grassroots Haitians and Haitian officials were used when compared to the Black Press' coverage. Among the most commonly-used U.S. sources were the Clinton administration officials, former President Jimmy Carter, Bush Administration officials, the Obama administration, and the Central Intelligence Agency (CIA). When Haitians were used, they were usually government officials, Aristide supporters, and Aristide opponents.

\section{Conclusion}

Aristide was portrayed by the Black Press as a savior of the poor, a corrupt politician, and a victim of U.S. foreign policy. The mainstream press depicted him as a savior of the poor, and a corrupt politician. Therefore, the mainstream and Black Press often covers stories similarly. However, nuances may occur in coverage when the information challenges the U.S. government. This was seen in the mainstream's omission of information about U.S. foreign policy towards Aristide and Haiti.

The Black Press' apparent willingness to report a view different than that of the U.S. government can be viewed as evidence that ethnic media are inclined to communicate "oppositional meanings" [33]. It shows their predisposition to report information that challenges the status quo and to publish information that may be considered "off the agenda" for the mainstream. The raison d'etreof ethnic mediais to be alternative to the mainstream, and be more representative of the people. Since Aristide still has mass support in Haiti and among the Haitian diaspora in the U.S., the Black Press would be likely to report more in a manner that the people, particularly the Haitians living in the U.S., would agree with.

The absence of that theme in the mainstream's coverage can be viewed as an intentional omission of information that would depict the U.S. government in a negative light. Given the longstanding history between the U.S. and Haiti-and Aristide in particular-it is unlikely that the journalists were oblivious to claims of U.S. misconduct in Haiti. Haiti's history with the U.S. is so inextricably linked, that it almost becomes imperative for U.S. journalists to report stories on Aristide, and Haiti in general, with some historical context. Apparently, the history between the two states affected the mainstream's coverage, in that; past information that negatively portrayed the U.S. government was not included. The mainstream reports that included historical information, reported on past information about Aristide and not necessarily on the past relationship between Aristide and the U.S. This allowed the mainstream to criticize him without having to criticize the U.S.

However, the consistent use of the themes of Aristide as the savior of the poor and a corrupt politician by both types of media gave an overall sense of a controversial figure. On the one hand, he was viewed as someone who fought for the common good of the Haitian masses, and who was the victim of U.S. hegemony. But on the other hand, the former president was depicted as a man with alleged links to corruption. This dichotomous view of Aristide reflects much of the literature used in chapter two of this thesis. While many authors such as Chomsky [5] and Reeves [22] focused more on the benefits Aristide brought to Haitians and the perceived wrong doings by the U.S., other writers such as Wucker [20] made salient his alleged ties to corruption. Thus, much of what was reported by the two types of media reflected much of existing literature.

It was also observed that the Black Press articles often included Haitians-proletariat Haitians, government officials, political enthusiasts, and so forth-as sources. This can be interpreted as the Black Press' likelihood to report information from Haitian's viewpoint, and not primarily from the U.S.' perspective. The mainstream did include Haitians as sources, but seemed more likely to use U.S. officials as sources. However, since they did make notable use of Haitians as sources, it can be interpreted that the mainstream press is not only dependent on U.S. officials as sources for international stories. 
Citation: Spencer AN (2012) A Comparative Analysis of the U.S. Mainstream Press and Black Press Coverage of Jean-Bertrand Aristide from 19912011. J Mass Commun Journalism 2:136. doi:10.4172/2165-7912.1000136

Page 13 of 14

\section{Final thoughts}

Having established the similarities and differences between the two types of media, it leads one to ponder whether the Black Press is really an alternative source of information to the mainstream in reports on Aristide. If consumers only read articles about Aristide from the Black Press or they only read articles from the mainstream, would the two sets of consumers walk away from the readings with a significantly different understanding of developments surrounding Aristide? Based on the results of this study, it seems fitting to conclude that the Black Press is sometimes alternative. It becomes alternative when it challenges the dominant narrative put forward by the U.S. government. However, the Black Press is often similar to the mainstream in coverage of Aristide, evidenced in the major similarities found. These major similarities found between the Black Press and the mainstream are prime examples of information control on a national level. Thus, although media outlets may be considered to be more subjective, the subjectivity is still limited.

\section{Future Research}

This study only analyzed coverage between mainstream and Black newspapers. However, future research can analyze coverage between mainstream television coverage and Black television coverage of Aristide. Also, other bodies of research can focus on a comparative analysis of reports by U.S. mainstream press versus those by the Haitian press. Another study can analyze the coverage by the mainstream and Black Press in 1995 when Republicans controlled the U.S. Congress. Such additional studies will lead to a more rounded understanding of mainstream and ethnic media coverage of Haiti's former president.

\section{References}

1. Gans HJ (1979) Deciding What's News: A Study of CBS Evening News, NBC Nightly News, Newsweek, and Time. New York NY: Vintage Bookd.

2. Dupuy A (1997) Haiti In The New World Order: The limits of the democratic revolution. Boulder CO: West view Press.

3. Fauriol G A (1995) Reinventing Democracy. In GA Fauriol (Ed), Haitian Frustrations Dilemmas for U.S.

4. Deuze M (2006) Ethnic Media, community media and participatory culture. Journalism 7: 262-280.

5. Chomsky H, Farmer P, Goodman A (2004) Getting Haiti Right This Time. Monroe, Maine: Common Courage Press.

6. Ulysse GA (2010) Why Representations of Haiti Matter Now More Than Ever NACLA Report on the Americas 43: 37-41.

7. White A (2010) Encountering Revolution: Haiti and the Making of the Early Republic. Baltimore MD: The Johns Hopkins University Press.

8. Dash JM (1997) Haiti and the United States: National Stereotypes and the Literary Imagination. New York, NY: St Martin's Press, Inc.

9. Schmidt H (1971) The United States Occupation of Haiti, 1915-1934. New Brunswick, NJ: Rutgers University Press.

10. Millspaugh AC (1970) Haiti under American Control, 1915-1930. Westport CT: Negro Universities Press.

11. Renda MA (2001) Taking Haiti Military Occupation and the Culture of U.S. Imperialism 1915-1940. North Carolina: The University of North Carolina Press.

12. Smith MJ (2009) Red \& Black in Haiti: Radicalism, Conflict, and Political Change 1934-1957. North Carolina: The University of North Carolina Press.

13. Trouillot M (1990) Haiti: State against Nation. New York: Monthly Review Press.

14. Chomsky N (2004) MADE IN AMERICA. Index on Censorship 2: 18-25.

15. Ballve T, Leech G (2004) Breaking Haiti. NACLA Report on the Americas 37: 7

16. Doyle K (1994) Hollow Diplomacy in Haiti. World Policy Journal 11: 50-58.

17. Reding A (1996) Exorcising Haiti's Ghosts. World Policy Journal 13: 15-26.
18. Human Rights Watch (1995) Haiti Human Rights after President Aristide's Return. 7.

19. Morley M, McGillion C (1997) Disobedient Generals and the Politics of Redemocratization: The Clinton Administration and Haiti. Political Science Quarterly 112: 363-383.

20. Wucker M (2004) Haiti: So Many Missteps. World Policy Journal 21: 41-49.

21. Regan J (2005) Haiti in Bondage to History? NACLA Report on The Americas 38: 4-7.

22. Reeves T (2003) Between a Sharp Tongue and a Blind Eye: The Politics of Criticism and Propa The Failings of Aristide. NACLA Report on The Americas 37: $44-47$

23. Preeg EH (1995) What Are the Real U.S. Interests in Haiti? In G.A. Fauriol (Ed.) Haitian Frustrations Dilemmas for U.S. Policy A Report of the CSIS Americas Program. Washington, D.C: The Center for Strategic and International Studies 7-12.

24. Potter AE (2009) Voodoo, Zombies, and Mermaids: U.S. Newspaper Coverage of Haiti. Geographical Review 99: 208-230.

25. Arthur C (2001) Raising the Stakes: Haiti between Mayhem and Decertification NACLA Report on the Americas, 35: 42-51.

26. Baumgartel E (2007) Good Guys and Bad Guys: A Content Analysis of New York Times and Washington Post Coverage of the 2004 Coup d'Etat in Haiti. A paper presented to the National Communication Association, Washington, D.C

27. Lule J (1997) News values in a new world: a Burkean analysis of the New York Times in Haiti 1994-96. Journal of Communication Inquiry 21: 3-24.

28. Downie A, Revah S (1995) Wanted: P.R. Director for Haiti. American Journalism Review 17: 14

29. Beeton D (2008) Bad News From Haiti: U.S. Press Misses the Story. NACLA Report on the Americas 41: 49-52.

30. Duvalier-Aristide? (2011) Equation of dictator with popular ex-president distorts Haitian history, reality FAIR.

31. Suggs HL (2002) The Response Of The African American Press To The United States Occupation Of Haiti, 1915-1934. Journal of African American History 87: $70-79$.

32. Walker D (1999) The Media's Role In Immigrant Adaptation: How First-Yea Haitians In Miami Use The Media. Journalism \&Communcation Monographs 1: 159-186.

33. Huspek M (2004) Black Press, White Press, and Their Opposition: The Case of the Police Killing of Tyisha Miller. Social Justice 31: 217-241.

34. Downing JDH (2003) Audiences and readers of alternative media: the absent lure of the virtually unknown. Media Culture \& Society 25: 625-644.

35. Shi Y (2009) Re-evaluating the 'alternative' role of ethnic media in the U.S: the case of Chinese-language press and working-class women readers. Media Culture \& Society 31: 597-616.

36. Cottle S (2000) Media Research and Ethnic Minorities: Mapping The Field In $S$ Cottle (Ed), Ethnic Minorities and the Media: Changing Cultural Boundaries Buckingham. Open University Press 1-30.

37. Matsaganis M, Katz V, Ball Rokeach SJ (2010) Ethnic media in local and global worlds. Thousand Oaks, CA: Sage.

38. Herman E, Chomsky N (1988) Manufacturing Consent The Political Economy of the Mass Media. New York: Pantheon Books.

39. Herman Noam \& Chomsky, Westminster Papers in Communication and Culture 6: 12-22.

40. Mullen A (2009) The Propaganda Model after 20 Years: Interview with Edward S. Pierre-Charles L, A Return to the Future. The Broward Times.

41. Klaehn J (2009) The Propaganda Model: Theoretical and Methodological Considerations. Westminster Papers in Communication and Culture 6: 43-58.

42. Fanon F (1967) Black Skin, White Masks. New York: Grove Press, Inc.

43. Foss S (2004) Rhetorical Criticism: Exploration and Practice. Illinois: Waveland Press.

44. Hanson C (1999) The Power of the Story: Narrative Analysis as A Tool For 
Citation: Spencer AN (2012) A Comparative Analysis of the U.S. Mainstream Press and Black Press Coverage of Jean-Bertrand Aristide from 19912011. J Mass Commun Journalism 2:136. doi:10.4172/2165-7912.1000136

Page 14 of 14

Studying The News. A paper presented to the Association for Education in Journalism and Mass Communication Conference, New Orleans, LA.

45. Robinson R (2004) Haiti at brink again, Final Call, NNPA database.

46. Daniels R (2010) Wyclef Jean for President of Haiti: Will He Be another Aristide? NNPA New America Media database.

47. Aikens C (1994) Aristide Denounces U.S. Policy, Oakland Post. Pro Quest Newspapers Ethnic News Watch.

48. Hinton C (2010) Rapper is No Friend of Haiti-Wyclef Opposed Aristide. San Francisco Bayview, New America Media database.

49. Lee Rips Bush on Aristide Downfall (2004) Sun Reporter, ProQuest Newspapers, And Ethnic News Watch.

50. Fletcher Jr B (2011) The Return of Aristide and Haiti's Failure, NNPA database.

51. Muhammad A (2011) Aristide returns as Haiti seeks new course. Final Call, NNPA database.

52. Malveaux J (2004) Malveaux At Large; Hypocrisy In Haiti? Sun Reporter. ProQuest Newspapers, Ethnic News Watch.

53. Muhammad A (2004) Activists, politicians question U.S. hand in Haiti crisis. Final Call NNPA database.

54. Joseph RA (2004) Kerry \& Co. Blindly Rush to Aristide's Rescue. The Broward Times, ProQuest Newspapers, Ethnic News Watch.

55. Dreyfuss J (2011) Qaddafi and Aristide: Dumped by a Fickle America. The Root, the Root database.

56. Fletcher JRB (2005) Haiti; One year later. Final Call, NNPA database.

57. (2011) Haiti Issues Exiled President Aristide a Passport to Return. Washington Afro.

58. (2011) Fraud Delays Preliminary Results of Haiti Election. Afro-American Newspapers, NNPA database.

59. Shabazz S (2011) Possible Aristide return increases Haiti's political drama. Final Call, NNPA database.
60. Dyer RA (1994) Hope Returns to Haiti; "My life is going to change now"; Elation rolls over crowds. The Houston Chronicle, LexisNexis database.

61. Manegold CS (1994) Mission to Haiti: The Scene; For Aristide's Followers Every Step Is a Dance, Every Cheer a Song. The New York Times, LexisNexis database.

62. Valbrun M (1994) Haiti Dusts Off Welcome Mat/Joy, Some Bitterness Await Aristide. The Philadelphia Inquirer, LexisNexis database.

63. Thompson G (2011) Haiti Agrees to Issue Passport For Aristide, Lawyer Says. The New York Times, LexisNexis database.

64. Miroff N (2011) Aristide set to return to Haiti ahead of vote. The Washington Post, LexisNexis database.

65. After Aristide; U.S. chose wisely over his troubles (2004). The Oklahoman LexisNexis database.

66. Lantigua J (2004) Former Backers of Aristide Now in Fear for Lives. Palm Beach Post, LexisNexis database.

67. (1994) Arisitide's Record; Voodoo Democracy. The Virginian-Pilot.

68. Gertz B (1995) Events seen backing CIA report; Sources: Agency right in labeling Aristide manic depressive. The Washington Times, LexisNexis database.

69. Farah D, Booth W (1994) Aristide Stirs Hopes, Fears of Haitians. The Washington Post, LexisNexis database.

70. Farah D (1997) In Haitian Infighting, Aristide Still Prevails; Handpicked Successor Suffers Accordingly. The Washington Post LexisNexis database.

71. Williams M (2001) Aristide takes office, calls for peace; Poor in Haiti joyous, but foes ready to act. The Atlanta Journal and Constitution.

72. Weymouth L (1993) Haiti's Suspect Savior; Why President Aristide's Return fromxile May Not Be Good News. The Washington Post, LexisNexis database.

73. Cave D (2011) Haiti Issues New Passport for Aristide. The New York Times LexisNexis database. 